progress should elucidate the nature of this change of style, but it cannot be neglected in any interpretation of the structure of the country discussed by Dr. Dearman.

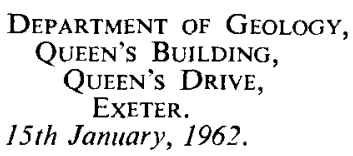

S. SIMPSON.

\title{
REFERENCES
}

Ashwin, D. P., 1958. The Coastal Outcrop of the Culm Measures of SouthWest England. Abstracts, South-West England Conference, $R$. geol. Soc. Cornwall, 2-3.

Dearman, W. R., 1962. Correspondence. Geol. Mag., 98, 529-530.

\section{FESTOON BEDDING}

SIR,--In 1960 (Geol. Mag., 97, 106-122) we gave a short account of festoon bedded sandstones from the Torridonian Epidotic Grits. Several people have taken the trouble to discuss this paper and particularly helpful analogies with younger deposits have been drawn by Prof. P. Allen, Dr. J. R. L. Allen, and their colleagues (Geol. Mag., 1960, 97, 261-263). More recently Dr. J. R. L. Allen (Liverpool and Manchester Geol. Journ., 1962, 3, 1-20) has given a most interesting account of festoon bedded sandstones from the Lower O.R.S. Comparison of the two accounts (Allen 1962, p. 10-11; Sutton and Watson 1960, p. 110-113) shows the O.R.S. and Torridonian deposits in question have much in common. In his discussion Dr. Allen makes a comment $(1962$, p. 15) which suggests that the two papers present radically different hypotheses as to the origin of festoon bedding. It seems to us that, though our nomenclature may differ, our underlying ideas are rather alike on this question.

Like Dr. Allen, we consider the structures are fluviatile. One suggestion of ours was that the Epidotic Grits could represent braided river deposits and we would readily accept the more detailed comparison with the braided channels of some swift sand-laden rivers, such as the Benue and the Niger, which Dr. Allen has made. Whatever the setting, and we agree that other environments are not out of question, an essential point seems to be that festoon bedding, as seen in the Epidotic Grits, developed as submerged irregular surfaces evolved. Troughs separated by cusps were present and step-like breaks occurred where deposits built out downstream. Such features were described by us and could be compared with systems of megaripples though we did not employ this term. We discussed the development of such irregular submerged surfaces and mentioned examples of the contemporaneous interplay of deposition and erosion, a point Dr. Allen has emphasized. We suggested that where festoon bedded grits overlie evenly bedded rocks, the lowest grits lie in troughs scoured out of the underlying beds (Sutton and, Watson, 1960, p. 111); compare Allen"s observation that "each unit was deposited on a smooth scoured surface cut into the upper part of the bed or beds below" (Allen, 1962, p. 13). Once this preliminary erosion had occurred we suggested, the succeeding sequence of festoon bedded grits built up a succession of irregular surfaces marked by a shifting system of troughs in which deposition and erosion proceeded contemporaneously (Sutton and Watson on p. 111, 113). In this way a channelled or megarippled bottom developed, the detailed topography of which was repeatedly changed. As we wrote in 1960 , "The form of the profile established during the development of the trough was maintained as the floor of the trough was built up ... profile was preserved by material being laid down on one bank and carried 
away from the other... in a general way the curve of the bank built up by the deposition of each new lamina resembles that of banks formed earlier in the development of the same trough. Thus, the three processes of preliminary erosion, deposition, and erosion combined with deposition all work to maintain the forms of the channels. Presumably the channelled type of surface was in equilibrium with the characteristics of the stream of water and detritus passing over it "(Sutton and Watson. p. 111). On a later page we discussed interdigitating deposits and noted that the rates of lateral migration may locally have been as great as that at which sediment was built out down stream.

Although we did not know it at the time, Hülsemann had already pointed out the possible connection between festoon bedding and megaripples (1955 Senck. lith., 36, 359-388). In drawing attention to Hülsemann's work Prof. Allen and Dr. Allen and their colleagues pointed to the resemblance between structures described by us and Hülsemann's megaripples (1960, p. 262). We accept this comparison as we do their interpretation of the Torridonian bottom of Epidotic Grit times as a maze of shifting hollows and impermanent hummocks. This puts succinctly a view we had ourselves attempted, though perhaps not very successfully, to convey in our paper.

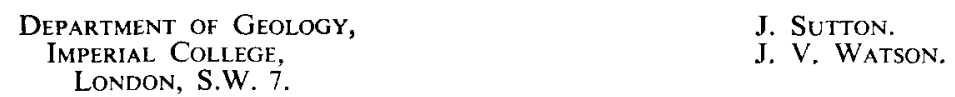
29th March, 1962. 